\title{
Estimation of somatic cell count levels of hard cheeses using physicochemical composition and artificial neural networks
}

\author{
P. A. Hernández-Ramos, ${ }^{1}$ A. M. Vivar-Quintana, ${ }^{2 *}$ and I. Revilla ${ }^{2}$ \\ ${ }^{1}$ Area de Expresión Gráfica en la Ingeniería, University of Salamanca, Escuela Politécnica Superior de Zamora, Avenida Requejo 33, \\ 49022 Zamora, Spain \\ ${ }^{2}$ Food Technology Area, University of Salamanca, Escuela Politécnica Superior de Zamora, Avenida Requejo 33, 49022 Zamora, Spain
}

\section{ABSTRACT}

This study addresses the prediction of the somatic cell counts of the milk used in the production of sheep cheese using artificial neural networks. To achieve this objective, the neural network was designed using 33 parameters of the physicochemical composition of the cheeses obtained after they have been matured for 12 mo as input data. The physicochemical analysis of the cheeses revealed that the somatic cell count level of the cheese has a significant influence on the amount of protein, fat, dry extract, and fatty acids. When properly set up, the neural network allows the correct classification of the cheeses $(100 \%$ of correct results in both training and test phases) and therefore their samples in each of the 3 nominal output variables (low, average, and high somatic cell counts). The fatty composition of the cheeses, individual fatty acids, and fat acidity are the variables that most affect the correct operation of the neural network.

Key words: somatic cell count, artificial neural network, cheese, classification

\section{INTRODUCTION}

The somatic cells found in milk from healthy animals are mainly macrophages and epithelial cells (Concha et al., 1986; Leitner et al., 2000). When an infection of the mammary gland occurs, an increase in SCC, mainly of polymorphonuclear neutrophils that may liberate proteolytic enzymes (Le Roux et al., 2003), can be observed (Poutrel, 1981). As a result SCC levels are often used as indicators of animal mammary disease. However, as has previously been pointed out by several authors, it is very hard to establish the SCC level indicative

Received March 21, 2018.

Accepted October 31, 2018.

*Corresponding author: avivar@usal.es of an inflammation of the mammary gland because it fluctuates considerably in ewe milk, and other factors such as age, animal husbandry practices, climate, and lactation stage may affect the SCC, with very high levels being reached during the colostral period and at the end of lactation (Dulin et al., 1983; Menzies and Ramanoon, 2001). Although EU Directives (EC, 2004) did not establish threshold values for the SCC in ewe milk, it has been suggested that a SCC value equal to 2,000,000 can be considered normal. Nevertheless, Boyazoglu and Morand-Fehr (2001) suggested a threshold level for subclinical mastitis in sheep close to 1,500,000 cells/mL, whereas Gonzalo et al. (2000) proposed that ovine flocks with $\mathrm{SCC}>1,000,000$ should indicate an unsatisfactory sanitary category.

The increase in the SCC of ewe milk leads to a decrease in the fat content, TS, caseins, and lactose amount and to an increase in whey proteins other than $\alpha-\mathrm{LA}$ and $\beta-\mathrm{LG}, \mathrm{pH}$, and fat acidity (Pirisi et al., 1996, 2000; Leitner et al., 2003; Albenzio et al., 2004; Revilla et al., 2007, 2009a,b; Rodríguez-Nogales et al., 2007). Moreover, the cheese-making properties of ewe milk with a high SCC are characterized by longer coagulation time, poorer syneresis, a lower cheese yield, higher protein and fat losses in the whey, and an increased curd moisture content (Pirisi et al., 1996; Jaeggi et al., 2003; Albenzio et al., 2004, 2011; Revilla et al., 2007). These poor cheese-making properties are due to an increase in proteolytic activity (Revilla et al., 2007, 2011; Albenzio et al., 2011; Pinto et al., 2013) due to the positive correlation between intact caseins and curding properties (Revilla et al., 2009b). The higher proteolytic activity and also lipolytic activity (Lurueña-Martínez et al., 2010a) affects the texture, flavor, and acceptability of hard ewe cheeses produced from milk with a high SCC. They have lower instrumental hardness and are described as softer, less creamy, more granulose, and also more rancid and pungent, and these cheeses were less popular with consumers (O'Farrell et al., 2002; Jaeggi et al., 2003; Revilla et al., 2007, 2009a; Lurueña-Martínez et al., 2010a). The undesirable ef- 
fects observed justify the use of the SCC to set milk prices (Kalantzopoulos et al., 2004).

Nonetheless, proteolytic and lipolytic activities are inherent to the cheese maturation process, and after several months it may be difficult to distinguish the SCC and the effects of time. In fact there were no significant differences in the percentage of proteolysis or chemical composition up until the sixth month of maturation, although higher fat acidity and higher $\mathrm{pH}$ was observed in high SCC milk cheeses (Jaeggi et al., 2003; Revilla et al., 2007, 2011) and some textural and flavor defects were reported after 12 mo of ripening (Lurueña-Martínez et al., 2010b). Despite the relevance of the SCC on cheese quality, no data regarding cheese classification according to this factor have been found.

Despite this, interest is growing in determining the quality and authenticity of dairy products; it is often not possible to make a definitive statement on cheese quality using only a physicochemical analysis due to the complexity of the matrix and the cheese-making process. The coupling of analytical and chemometric tools has proved to be very useful in product authenticity and authentication (Karoui and De Baerdemaeker, 2007). Among chemometric tools, the artificial neural network (ANN) is well suited for food quality prediction because it can handle complex nonlinear relationships with ease, even when the exact nature of such behavior is unclear. For this reason ANN are being widely used in several disciplines for modeling complex real-world problems (Basheer and Hajmeer, 2000).

Artificial neural networks have been used successfully in the dairy industry to predict shelf life (as reviewed by Goyal and Goyal, 2012), physicochemical composition (Etzion et al., 2004; Khanmohammadi et al., 2009), and sensory characteristics (Singh et al., 2009; Cruz et al., 2011); to discriminate varieties, geographical origin, or seasonal variations (He et al., 2005; Cruz et al., 2009, 2013; Gori et al., 2012); to control milk quality (Hettinga et al., 2008; Souza et al., 2011); and to model operational parameters during product manufacture (Funahashi and Horiuchi, 2008). As far as cheese manufacture is concerned, ANN have been applied mainly for authentication, classification, or traceability purposes (Pillonel et al., 2005; Zeppa et al., 2005; Barile et al., 2006; Verdini et al., 2007; Cevoli et al., 2011, 2013) but also for predicting ripening (Soto-Barajas et al., 2013) or moisture (Jimenez-Marquez et al., 2003, 2005) or the optimization of the cheese-making process (Paquet et al., 2000; Horiuchi et al., 2004).

In this study we developed an ANN model to predict the SCC levels of the raw ewe milk used for hard cheese manufacture. The physicochemical composition, color, texture, and individual fatty acids analyzed at different stages of cheese ripening (up to $12 \mathrm{mo}$ ) were selected as input variables. The ANN model was also used to identify the most important factors of the predicted variable and to study its relationships with the dependent variable.

\section{MATERIALS AND METHODS}

\section{Milk Collection}

Different milk samples were taken from bulk milk of herds with 3 SCC: less than 500,000 cells $/ \mathrm{mL}$ (low SCC), between 1,000,000 and 1,500,000 cells/mL (average SCC), and between 2,500,000 and 3,000,000 cells/ $\mathrm{mL}$ (high SCC). The upper and lower limits were set according to the highest and lowest SCC values found in the region throughout the year. The herds (3 herds for each SCC level) were selected on the basis of the milk SCC recorded during the previous months, choosing herds with a SCC that was always within the limits of each group.

All herds were reared in Zamora (Spain) under identical husbandry systems and feeding regimens. Samples were taken from bulk milk from the first week of November until the first week of December for 2 consecutive years. During this period the ewes were in the mid-lactation stage; the animals were kept in stables, fed with concentrates composed of beetroot pulp, alfalfa, barley, corn, soy, and cotton, and were machine-milked. On the sampling day, an aliquot was submitted for Fossomatic SCC analyses and total bacteria counts at the certified laboratory of the Regional Government of Castilla y León, Spain. The results showed that the samples were within the range initially selected for SCC. Regarding bacterial counts, the group of sheep milk with low SCC values showed low bacterial levels, whereas no significant differences were observed between the groups of sheep milk with average and high SCC values.

\section{Cheese-Making Procedure}

Nonstandardized raw milk (40 L) was incubated with $36 \mathrm{mg} / \mathrm{L}$ of direct-vat-set starters consisting of Streptococcus lactis, Streptococcus cremoris, and Streptococcus diacetylactis (MA400, Choozit, Danisco, Sassenage, France) at $30^{\circ} \mathrm{C}$. After $30 \mathrm{~min}$ at $32^{\circ} \mathrm{C}$, when the $\mathrm{pH}$ was 6.5 to $6.6,11.25 \mathrm{mg} / \mathrm{L}$ of calf rennet (90\% chymosin, 10\% pepsin, 1:150,000 strength) was added to each vat. Coagulation was allowed to take place over 40 to $70 \mathrm{~min}$. When the coagulum had developed the desired firmness, evaluated subjectively, the curds were 
cut with a cheese harp until pieces similar in size to a grain of rice had been obtained. Subsequently the curd was stirred for $30 \mathrm{~min}$ and heated for $20 \mathrm{~min}$ at $36^{\circ} \mathrm{C}$ until it had reached the desired consistency to improve its drainage with sieves. The curd was packed in round hoops $(1 \mathrm{~kg})$ and pressed for $5 \mathrm{~h}$ at $1.5 \mathrm{~kg} \cdot \mathrm{cm}^{-2}$ at $20^{\circ} \mathrm{C}$. After pressing the cheeses were salted by soaking them in sodium chloride brine $\left(16^{\circ}\right.$ Baumé) at $18^{\circ} \mathrm{C}$ for 12 $\mathrm{h}$. The cheeses were then moved to a drying chamber where temperature was $15^{\circ} \mathrm{C}$ and relative humidity was $78 \%$ during the first month, $70 \%$ during the second and third months, and $66 \%$ until ripening was completed. For each manufacturing process 2 cheeses were removed from each vat for analysis after the cheese-making process $(0 \mathrm{mo})$ and after $3,6,9$, and 12 mo of ripening.

\section{Physicochemical Analysis}

All compositional analyses were carried out in triplicate. Cheese samples were analyzed for $\mathrm{pH}$ (potentiometric method, CRISON Basic20), fat (Van Gulik method; ISO, 1975), dry extract (IDF, 1982), ashes (AOAC International, 2000), and fat acidity (IDF, 1969). The total amount of nitrogen (AOAC International, 1995) was determined by using the Kjeldahl method and the results were expressed as protein equivalents (total $\mathrm{N}$ $\times 6.38)$ on the basis of dry extract. Water activity was determined $\left(\mathrm{a}_{\mathrm{w}}\right)$ in grated cheese with $\mathrm{a}_{\mathrm{w}}$ Sprint equipment (Novasina, Axair Ltd., Pföffikan, Switzerland).

Color was measured on a 1-cm-thick slice from the central diameter of each cheese wheel by using a MiniScan XEPlus (Hunter Lab, Reston, VA) with a 25$\mathrm{mm}$ measuring head and diffuse $/ 8^{\circ}$ optical geometry. The CIELab parameters were calculated for the CIE illuminant $\mathrm{D}_{65}$ and $10^{\circ}$ standard observer conditions. The parameters calculated were lightness $\left(\mathrm{L}^{*}\right)$, redness $\left(a^{*}\right)$, and yellowness (b*; CIE, 1975). The color was determined on the surface of a cheese slice ( $1 \mathrm{~cm}$ thick) obtained by cutting the cheese into 2 halves. Determinations were carried out in triplicate in the center and on the edges of the slice.

Samples for cheese textural analysis had been kept at $24^{\circ} \mathrm{C}$ for $1 \mathrm{~h}$ before the analysis and were obtained by cutting the 1-cm-thick slice from the central diameter into 6 rectangular parallelepipeds, $1 \times 1 \mathrm{~cm}$ thick and $3 \mathrm{~cm}$ long. A TX-T2iplus equipped with a Warner-Bratzler probe (Stable Micro Systems, Surrey, UK) was used to determine the instrumental texture. The crosshead speed was $1 \mathrm{~mm} / \mathrm{s}$, and the maximum peak force (Warner-Bratzler shear force) necessary to cut each parallelepiped transversally and completely was recorded.

\section{Fatty Acid Analysis}

The fatty acids were determined by following the method described by Lurueña-Martínez et al. (2010a). Lipids were extracted using the International Standard Method described in ISO 14156:2001 (ISO, 2001). Fatty acids of all samples were methylated and analyzed by GC (GC 6890 N, Agilent Technologies, Santa Clara, CA) using a $100 \mathrm{~m} \times 0.25 \mathrm{~mm} \times 0.20 \mu \mathrm{m}$ capillary column (SP-2560, Supelco Inc., Bellefonte, PA). The oven temperature program was $150^{\circ} \mathrm{C}$, increasing temperature at $1^{\circ} \mathrm{C} / \mathrm{min}$ to reach $165^{\circ} \mathrm{C}$, then increasing at $0.20^{\circ} \mathrm{C} / \mathrm{min}$ to reach $167^{\circ} \mathrm{C}$ and then increasing by $1.50^{\circ} \mathrm{C} / \mathrm{min}$ to reach $225^{\circ} \mathrm{C}$, where it was maintained for $15 \mathrm{~min}$. One microliter was injected into the chromatograph, equipped with a split/splitless injector and an flame ionization detector. The injector and detector temperatures were $250^{\circ} \mathrm{C}$. The carrier gas was helium at $1 \mathrm{~mL} / \mathrm{min}$ and split (20:1). The different fatty acids were identified by the retention time compared with the corresponding standards including the 4 CLA isomers CLA cis-9,trans-11, CLA trans-10,cis-12, CLA cis-9,cis-11, and CLA trans-9,trans-11 (Larodan Fine Chemicals AB, Malmo, Sweden). Fatty acid contents were calculated using chromatogram peak areas and were expressed as grams per $100 \mathrm{~g}$ of total of fatty acid methyl esters.

\section{Artificial Neural Network}

Artificial neural network models were performed using Matlab 8.1 (R2017a, MathWorks Inc., Natick, MA). A multi-layered feed-forward network with backpropagation was built to predict the specific classes to which the samples belong. The tangent sigmoid and pure linear transfer functions were used in the hidden and output layers, respectively. The weight and bias matrix was randomly initialized but by using the same seed value that allows the reproducibility of data (Pillonel et al., 2005). The error minimization process was achieved by using the gradient descent method. General architecture of this ANN includes an input, an output, and 1 hidden layer. The input layer had 33 neurons corresponding to the different parameters quantified in the samples summarized in Table 1 . Three nominal output variables (low SCC, average SCC, and high SCC) were used to perform classification tasks: the target output is 1.0 in the correct class output and 0.0 in the others (Cevoli et al., 2011; Gori et al., 2012). Networks with one hidden layer but with different number of neurons were tested to select the most accurate classification results. 
The original data set (80 observations) was divided at random into a training set (70\%, 56 observations), a verification set $(15 \%, 12$ observations), and a test set (15\%, 12 observations) for all ANN tested. The verification set was used to identify the best network and to indicate possible overlearning, and the test set was treated as an unknown so as to provide an independent assessment of the classifying capability of the network.

The best network structure selection was performed using several criteria: the confusion matrices (training, verification, and test sets) that account for the samples that were correctly classified, the mean square error (MSE), and the plot of receiver operating characteristics that correlates the false positive rate with the true positive rate.

\section{RESULTS AND DISCUSSION}

\section{Analytical Results}

Table 1 shows the yearly average values obtained from the physicochemical analysis of low SCC (less than 500,000 cells $/ \mathrm{mL}$ ), average SCC (between 1,000,000 and $1,500,000$ cells $/ \mathrm{mL}$ ), and high SCC (between 2,500,000 and $3,000,000$ cells $/ \mathrm{mL}$ ) milk cheeses and the statistical significance of the 3 factors considered: the SCC level, the month of ripening, and the year of sampling.

Results show a significant effect of the SCC on protein content that underwent a statistically significant increase as the SCC values increased. This result differs from those previously reported by other authors who

Table 1. Mean values of the parameters analyzed of hard ewe milk cheeses in different SCC groups

\begin{tabular}{|c|c|c|c|c|c|c|}
\hline \multirow[b]{2}{*}{ Item } & \multicolumn{3}{|c|}{$\mathrm{SCC}(\times 1,000 / \mathrm{mL})$} & \multicolumn{3}{|c|}{ Significance } \\
\hline & $<500$ & $1,000-1,500$ & $2,500-3,000$ & $\mathrm{SCC}$ & Month & Year \\
\hline $\mathrm{pH}$ & 5.33 & 5.35 & 5.37 & NS & $* * *$ & NS \\
\hline Fat $^{1}(\%)$ & $54.04^{\mathrm{b}}$ & $53.35^{\mathrm{ab}}$ & $52.60^{\mathrm{a}}$ & $*$ & NS & $* * *$ \\
\hline Protein $^{2}(\%)$ & $38.90^{\mathrm{a}}$ & $39.70^{\mathrm{ab}}$ & $40.07^{\mathrm{b}}$ & $*$ & NS & $* * *$ \\
\hline $\operatorname{Ash}^{3}(\%)$ & 6.84 & 6.87 & 7.10 & NS & NS & $* * *$ \\
\hline Dry extract (\%) & $77.79^{\mathrm{b}}$ & $76.64^{\mathrm{a}}$ & $77.02^{\mathrm{ab}}$ & $*$ & $* * *$ & NS \\
\hline Water activity & $0.853^{\mathrm{ab}}$ & $0.858^{\mathrm{b}}$ & $0.845^{\mathrm{a}}$ & $*$ & $* * *$ & $* *$ \\
\hline Fat acidity ${ }^{4}$ & $3.76^{\mathrm{a}}$ & $5.44^{\mathrm{b}}$ & $8.79^{c}$ & $* * *$ & $* * *$ & $* * *$ \\
\hline $\mathrm{L}^{* 5}$ & 78.45 & 78.94 & 79.94 & NS & $* * *$ & $* * *$ \\
\hline$a^{* 5}$ & -0.538 & -0.069 & 0.294 & NS & $* * *$ & NS \\
\hline $\mathrm{b}^{* 5}$ & $20.09^{\mathrm{b}}$ & $18.88^{\mathrm{a}}$ & $18.95^{\mathrm{a}}$ & $*$ & $* * *$ & NS \\
\hline $\mathrm{WBSF}^{6}(\mathrm{~N})$ & $29.94^{\mathrm{b}}$ & $25.33^{\mathrm{a}}$ & $25.56^{\mathrm{a}}$ & $*$ & $* * *$ & $* * *$ \\
\hline \multicolumn{7}{|l|}{ Fatty acid } \\
\hline Butyric (C4:0) & 1.45 & 1.38 & 1.39 & NS & $* * *$ & NS \\
\hline Caproic (C6:0) & 2.12 & 2.11 & 2.11 & NS & $* * *$ & NS \\
\hline Caprylic (C8:0) & 2.59 & 2.66 & 2.68 & NS & $* * *$ & NS \\
\hline Capric (C10:0) & 8.24 & 8.79 & 9.22 & NS & $* * *$ & NS \\
\hline Lauric (C12:0) & $4.68^{\mathrm{a}}$ & $5.01^{\mathrm{ab}}$ & $5.34^{\mathrm{b}}$ & $*$ & $* * *$ & NS \\
\hline Myristic (C14:0) & $10.42^{\mathrm{a}}$ & $11.17^{\mathrm{b}}$ & $11.76^{\mathrm{b}}$ & $* * *$ & $*$ & $* *$ \\
\hline Myristoleic (C14:1) & $0.17^{\mathrm{a}}$ & $0.22^{\mathrm{b}}$ & $0.23^{\mathrm{b}}$ & $* *$ & $*$ & $* *$ \\
\hline Palmitic (C16:0) & 25.23 & 25.04 & 24.86 & NS & $* * *$ & NS \\
\hline Palmitoleic (C16:1) & $1.13^{\mathrm{a}}$ & $1.22^{\mathrm{b}}$ & $1.25^{\mathrm{b}}$ & $* *$ & NS & NS \\
\hline Heptadecanoic (C17:0) & 0.62 & 0.65 & 0.63 & NS & $* * *$ & $* * *$ \\
\hline Heptadecenoic (C17:1) & 0.18 & 0.20 & 0.19 & NS & NS & NS \\
\hline Stearic (C18:0) & 12.04 & 11.44 & 11.19 & NS & $* * *$ & NS \\
\hline Elaidic (C18:1 trans) & 2.01 & 1.69 & 1.43 & NS & NS & NS \\
\hline Oleic (C18:1) & 18.20 & 18.23 & 18.03 & NS & $* * *$ & NS \\
\hline Linoleic (C18:2) & 2.74 & 2.46 & 2.23 & NS & NS & NS \\
\hline Araquidic (C20:0) & $0.05^{\mathrm{a}}$ & $0.05^{\mathrm{a}}$ & $0.06^{\mathrm{b}}$ & $*$ & NS & NS \\
\hline Linolenic (C18:3) & $0.50^{\mathrm{ab}}$ & $0.52^{\mathrm{b}}$ & $0.43^{\mathrm{a}}$ & $*$ & NS & NS \\
\hline Eicosapentaensic acid (C20:5) & 0.04 & 0.04 & 0.04 & NS & NS & NS \\
\hline Docosahexaenoic acid (C22:6) & 0.02 & 0.02 & 0.02 & NS & NS & NS \\
\hline CLA (cis-9,trans-11) & $0.53^{\mathrm{b}}$ & $0.45^{\mathrm{a}}$ & $0.41^{\mathrm{a}}$ & $* *$ & NS & $* *$ \\
\hline CLA $($ cis-9, cis-11) & $0.07^{\mathrm{b}}$ & $0.07^{\mathrm{ab}}$ & $0.06^{\mathrm{a}}$ & $*$ & NS & $*$ \\
\hline CLA (trans-9,trans-11) & 0.04 & 0.04 & 0.04 & NS & NS & $* * *$ \\
\hline
\end{tabular}

${ }^{a-c}$ Values followed by different letter in the same row differ significantly according to the Tukey test $(P<0.05)$.

${ }^{1}$ Fat content on a dry weight basis.

${ }^{2}$ Total $\% \mathrm{~N} \times 6.38$, on a dry weight basis.

${ }^{3}$ Ash on a dry weight basis.

${ }^{4} \mathrm{mg}$ of $\mathrm{KOH}$ per gram of fat.

${ }^{5} \mathrm{~L}^{*}=$ lightness; $\mathrm{a}^{*}=$ redness; $\mathrm{b}^{*}=$ yellowness.

${ }^{6} \mathrm{WBSF}=$ Warner-Bratzler shear force.

${ }^{*} P \leq 0.05 ;{ }^{* *} P \leq 0.01 ;{ }^{* * *} P \leq 0.001$. 
either failed to find significant differences among SCC levels both in freshly elaborated and ripened cheese (Pirisi et al., 2000; Jaeggi et al., 2003; Nudda et al., 2003; Revilla et al., 2011, 2009b) or found significantly lower values of casein content, both $\alpha-\mathrm{CN}$ and $\beta-\mathrm{CN}$, as the SCC increased (Revilla et al., 2011, 2007), which is attributable to the higher proteolytic activity as the SCC increased (Albenzio et al., 2004, 2011).

The fat content was significantly lower in cheeses with higher SCC levels, due to the lower initial milk fat content of high SCC milk (low SCC $=8.65 \%$; average $\mathrm{SCC}=8.49 \%$, high $\mathrm{SCC}=7.52 \%)$ and to a higher lipolytic activity as previously observed for high SCC cow milk (Gargouri et al., 2008). The higher lipolytic activity of high SCC cheeses is due to the lipase activity of somatic cells that produces higher concentrations of free fatty acids (Albenzio et al., 2011), increasing fat acidity. Thus, it may be seen that fat acidity was significantly higher in the cheeses with a high SCC, with the differences being wider as ripening progressed.

The dry extract was significantly affected by SCC levels and low SCC cheeses have higher values of this parameter, which is in agreement with previous research that reported higher moisture values for cheeses made from milk with high SCC levels (Jaeggi et al., 2003; Albenzio et al., 2004; Revilla et al., 2009b). This result may be due to an alteration in the milk protein composition and mineral balance (Munro et al., 1984), but the somatic cells themselves may also contribute to the higher cheese moisture content (Marino et al., 2005). High moisture levels are known to accelerate proteolysis [and the increase of moisture with the SCC may have promoted higher proteolysis in the cheese (Jaeggi et al., 2003)]. However, water activity was significantly lower in high SCC cheeses, because the higher the proteolysis and lipolysis the higher the release of AA, peptides, organic acids, and calcium phosphate, which are the compounds that reduce water activity.

Low SCC cheeses had significantly higher values of $\mathrm{b}^{*}$ as they were more yellow than average SCC and high SCC cheeses, but we observed no significant differences for L* and a*. The results of Rohm and Jaros (1997) indicated that the yellowness index increased with the unsaturation of fat and DM content, mainly with the amount of fat (Sánchez-Macías et al., 2010), and results showed that low SCC cheeses showed significantly lower levels of SFA (low $\mathrm{SCC}=67.44$, average $\mathrm{SCC}=68.30$, high $\mathrm{SCC}=69.24)$ and higher levels of dry extract and fat content as shown in Table 1.

Cheese texture determined as Warner-Bratzler shear force showed a significant decrease when there was an increase from low to average SCC levels. Textural problems in ewe cheeses as the SCC increases have been previously observed both in recently manufactured (Pirisi et al., 2000) and in matured cheese (Jaeggi et al., 2003; Revilla et al., 2009a). These problems are related to the higher moisture that reduces the coherence of the protein matrix (Fox et al., 2000), but mainly to the higher proteolysis in high SCC cheeses that reduces the strength of the gel and decreases the shear force (Revilla et al., 2009a). Previous studies revealed higher amounts of fragment I of $\alpha_{\mathrm{S1}}$-casein in high SCC cheeses, which is associated with cheese texture problems such as increased crumbliness (Irigoyen et al., 2000; Sousa et al., 2001; Revilla et al., 2007).

Finally, the SCC showed no significant effect on ash content and $\mathrm{pH}$ tended to show higher values as the SCC increased, which agreed with previous studies (Revilla et al., 2007, 2009b), but in this case the differences were not statistically significant.

Fatty acid composition showed a significant effect on the SCC in 8 out of 23 individual fatty acids quantified. Among these, SFA (lauric, myristic, and araquidic acids) and MUFA (myristoleic and palmitoleic) had significantly lower values in low SCC cheeses, whereas PUFA levels (linolenic and 2 CLA isomers) were significantly higher, which was in contrast to previous studies that failed to find any differences in the fatty acid profile due to the SCC (Laurinaviciute et al., 2004).

The month of ripening significantly affected dry extract and water activity due to the progressive loss of water during maturation. This process was also mainly responsible for the increase in Warner-Bratzler shear force. Fat acidity increased because as cheese ages the total free fatty acid content also increases (Pavia et al., 2000), which also affects the $\mathrm{pH}$ values. As far as cheese color is concerned, $\mathrm{L}^{*}$ was significantly lower while $a^{*}$ and $b^{*}$ were significantly higher as ripening progressed due to the proteolytic and lipolytic process and to the increase in DM (Rohm and Jaros, 1997). Finally, ripening significantly affected SFA because a significant increase in short-chain SFA together with an increase in long-chain SFA was observed in both years in the third month of maturation.

The year of manufacture significantly affected fat, protein, ash, and water activity and this may also account for the observed differences in color and texture. Finally, lipolysis was more intense in the first year with higher mean values of fat acidity (7.16 vs. 6.67) being attained.

\section{ANN Modeling}

The best network structure selection was performed using several criteria: the confusion matrix (training, verification, and test sets) that accounts for the sam- 
Table 2. Results of artificial neural network with 33 input units and 3 nominal output variables (low, average, and high SCC): the mean square error (MSE) and correctly classified cases (\%)

\begin{tabular}{|c|c|c|c|c|c|}
\hline \multirow{2}{*}{$\begin{array}{l}\text { No. of neurons } \\
\text { in the hidden layer }\end{array}$} & \multirow[b]{2}{*}{ MSE } & \multicolumn{4}{|c|}{ Correct classification cases $(\%)$} \\
\hline & & Training & Validation & Test & Total \\
\hline 3 & 0.295 & 55.3 & 41.6 & 50.0 & 52.5 \\
\hline 4 & 0.336 & 44.6 & 41.6 & 33.3 & 42.5 \\
\hline 5 & 0.304 & 51.7 & 58.3 & 33.3 & 50.0 \\
\hline 6 & 0.288 & 58.9 & 50.0 & 83.3 & 61.2 \\
\hline 7 & 0.354 & 42.8 & 33.3 & 16.6 & 37.5 \\
\hline 8 & 0.171 & 100.0 & 100.0 & 100.0 & 100.0 \\
\hline 9 & 0.337 & 44.6 & 58.3 & 25.0 & 43.7 \\
\hline 10 & 0.217 & 91.0 & 83.3 & 83.3 & 88.7 \\
\hline 11 & 0.286 & 64.2 & 58.3 & 41.6 & 60.0 \\
\hline 12 & 0.326 & 46.4 & 50.0 & 50.0 & 47.5 \\
\hline 13 & 0.224 & 89.2 & 75.0 & 66.6 & 83.7 \\
\hline 14 & 0.264 & 71.4 & 75.0 & 50.0 & 68.7 \\
\hline 15 & 0.224 & 91.0 & 66.6 & 58.3 & 82.5 \\
\hline 16 & 0.228 & 83.9 & 91.6 & 83.3 & 85.0 \\
\hline 17 & 0.215 & 87.5 & 83.3 & 58.3 & 82.5 \\
\hline 18 & 0.235 & 87.5 & 66.6 & 50.0 & 78.7 \\
\hline 19 & 0.299 & 57.1 & 66.6 & 50.0 & 57.5 \\
\hline 20 & 0.324 & 53.5 & 50.0 & 33.3 & 50.0 \\
\hline 21 & 0.322 & 48.2 & 50.0 & 50.0 & 48.7 \\
\hline 22 & 0.316 & 58.9 & 33.3 & 25.0 & 50.0 \\
\hline 23 & 0.239 & 82.1 & 66.6 & 66.6 & 77.5 \\
\hline 24 & 0.348 & 19.6 & 66.6 & 25.0 & 27.5 \\
\hline 25 & 0.361 & 37.5 & 50.0 & 50.0 & 41.2 \\
\hline 26 & 0.256 & 78.5 & 50.0 & 75.0 & 73.7 \\
\hline 27 & 0.346 & 46.4 & 50.0 & 25.0 & 43.7 \\
\hline 28 & 0.199 & 100.0 & 75.0 & 66.6 & 91.2 \\
\hline 29 & 0.302 & 67.8 & 33.3 & 33.3 & 57.5 \\
\hline 30 & 0.356 & 33.9 & 58.3 & 25.0 & 36.2 \\
\hline 31 & 0.274 & 73.2 & 50.0 & 50.0 & 66.2 \\
\hline 32 & 0.363 & 32.1 & 50.0 & 41.6 & 36.2 \\
\hline 33 & 0.200 & 96.4 & 75.0 & 75.0 & 90.0 \\
\hline
\end{tabular}

ples that were correctly classified, the MSE, and the plot of receiver operating characteristics that correlates the false positive rate with the true positive rate. As it is recommended that the number of neurons in the hidden layer should be between the input and the output layer size and determined empirically (Berry and Linoff, 1997; Borguer and Guterman, 1997), networks with one hidden layer but with several neurons ranging from 3 to 33 were tested to select that with the best classification ability. The results of the MSE and the training, validation, and testing to the neural networks are summarized in Table 2. A total of 60,000 RNA have been trained. For each configuration (from 3 to 33 neurons in the hidden layer), 1,000 RNA were trained.

The best ANN configuration for classifying cheeses correctly in accordance with the SCC of the milk used in their production is that presenting 8 neurons in the hidden layer. This ANN configuration gave the best results for each of the selection criteria used, classifying $100 \%$ of the samples correctly and having the lowest MSE of all the networks tested.
According to Demuth and Beale (1994), when the verification error increases for a certain number of interactions, the training must be stopped. The training and validation errors were monitored during the process (Figure 1). Training, validation, and test median errors decreased continuously with the number of interactions; the training was stopped after 49 epochs before the network began to overfit the data and the errors on the verification set began to increase.

\section{Identification of Important Input Variables}

The effect of each input variable on the modeled variables was evaluated by analyzing the weights of each of the inputs of the neurons of the hidden layer. The neurons of a neural network are activated or inhibited in accordance with the inputs they receive and the "importance" of these inputs regarding the problem to be solved. This importance is represented as a "weight" for each input in the form of numerical values that multiply the values of each input. The final state of excitation is determined by comparing the inputs, weighted by their respective values, with a threshold value or "bias." The final result of the training process of a neural network is the determination of the values that the bias and weights must have to solve the problem for which the network has been trained.

In our case the neural network is programmed with a ToolBox of the Matlab program (of MathWorks). Once the training stage has been completed, these values

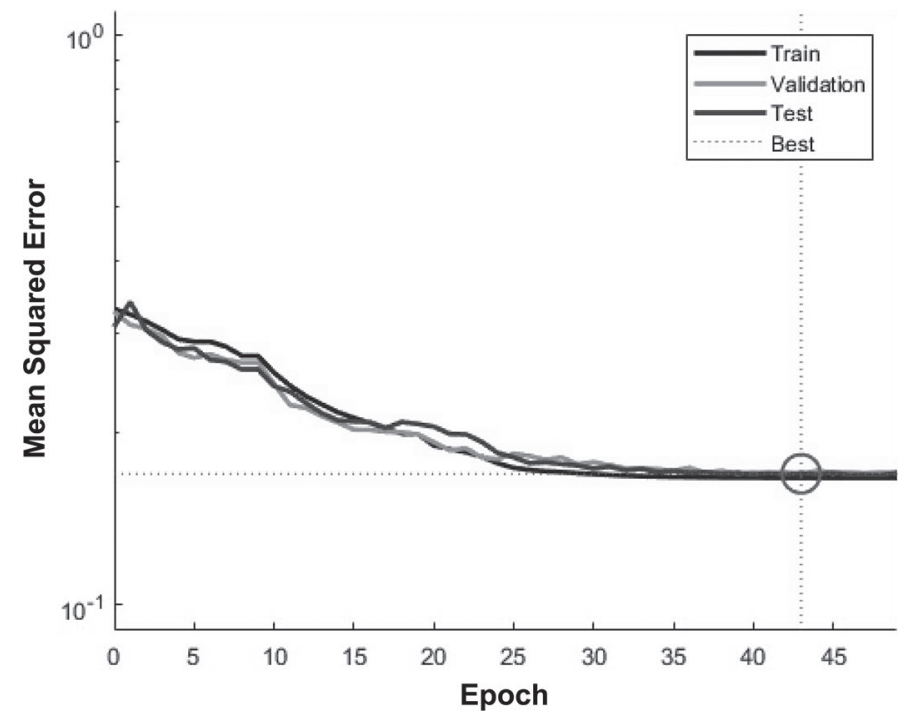

Figure 1. Plot of the mean square error relative history with 33 input units and 8 neurons in the hidden layer. Best validation performance is 0.16951 at epoch 43 . 
Table 3. Weights of each of the inputs in each of the 8 neurons of the hidden layer obtained by means of ToolBox from the Matlab (MathWorks, Natick, MA) program

Neurons in the hidden layer

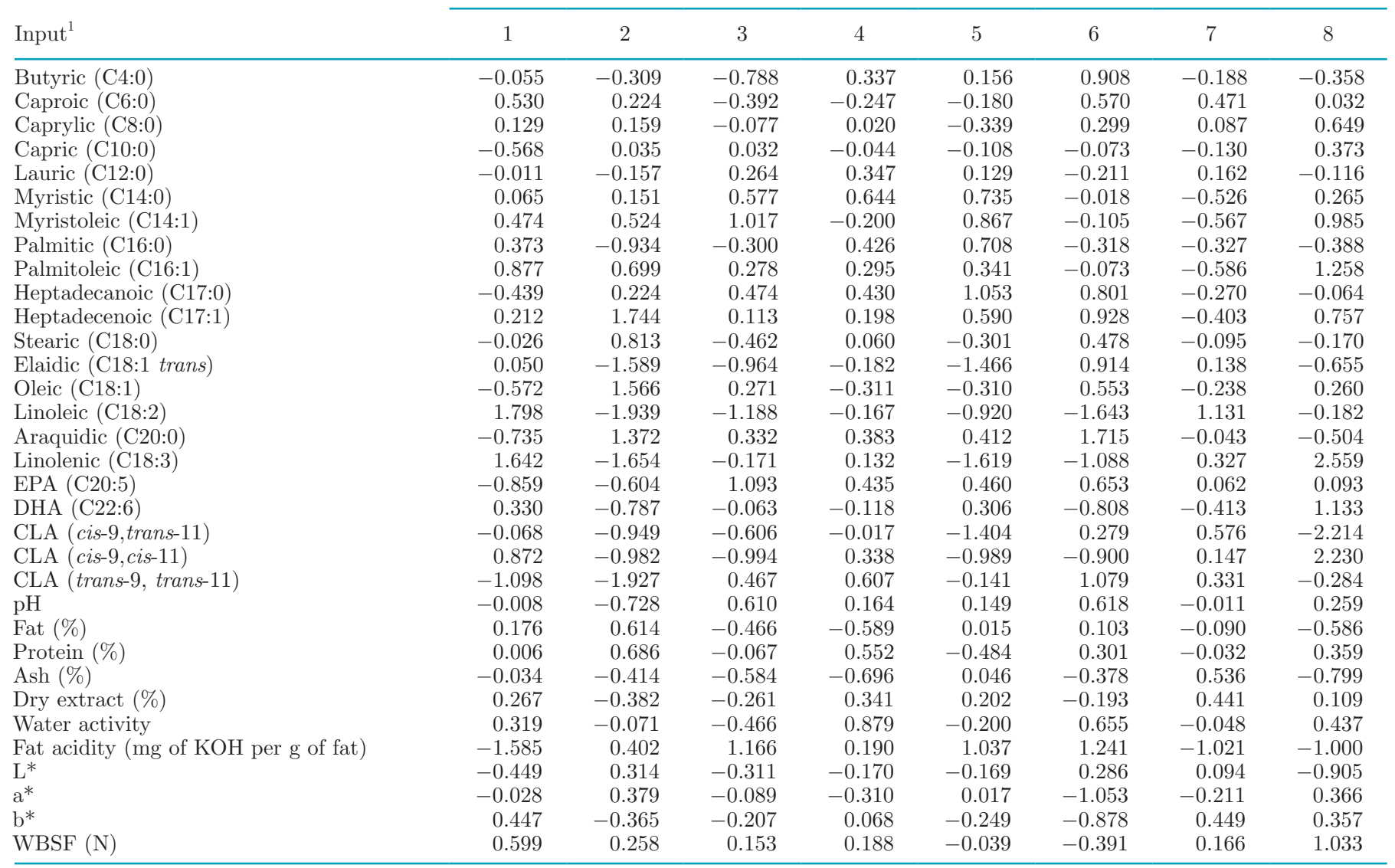

${ }^{1} \mathrm{EPA}=$ eicosapentaenoic acid; DHA $=$ docosahexaenoic acid; $\mathrm{L}^{*}=$ lightness; $\mathrm{a}^{*}=$ redness; $\mathrm{b}^{*}=$ yellowness; WBSF $=$ Warner-Bratzler shear force.

can be stored on a multidimensional array that can be transformed into 3 arrays by means of the "separateweb" function of the ToolBox itself. In this way we can obtain data on the weight of each of the inputs of the neurons of the hidden layer (Table 3).

In view of these results, we can observe how in the network training process different weights (positive or negative) have been allocated to each of the inputs of each of the neurons of the hidden layer. The absolute weight of each input on the neuron gives us an idea of the importance of this input on the correct classification capacity of said neuron. To analyze the results obtained in a simple manner, it was decided to calculate the quadratic weight of each of the inputs, which can be understood as the sum of the squared weight of each of the 8 neurons of the hidden layer, allocated by the neural network for that parameter. The data obtained are shown in Figure 2. The fatty composition of the cheese has a considerable influence when predicting correctly the SCC of the milk used to produce it. The variables that most contribute to the correct operation of our network are linoleic (C18:2) and linolenic (C18:3) acid followed by CLA isomers and fat acidity.

The levels of linoleic acid, linolenic acid, and CLA isomers were higher in cheeses produced with low SCC (Table 1), and similar results were found by Coelho et al. (2017) in cow milk cream with a low SCC. Milk with different SCC presents different profiles of endogenous enzymes entailing different degrees of lipolysis, which give rise to dairy products with different characteristics (Li et al., 2014). These longer-chain fatty acids are derived from blood lipids produced during the digestion and absorption of dietary fat or from the mobilization of fatty acids from adipose tissue (Zeppa et al., 2003). These fatty acids might be further modified in the mammary gland through the activity of desaturase enzymes (Vlaeminck et al., 2006). It has been suggested that the lower concentrations of these compounds in milk with high SCC may be related to reduced food intake by the sheep (Carboni et al., 2017), as was already observed 
in cows affected by clinical mastitis (Sepúlveda-Varas et al., 2014).

Another important parameter of the network is fat acidity. As we have already seen in Table 1, as the SCC increased, higher fat acidity values were also observed.
The SCC is an important source of endogenous proteins including enzymes; a wide range of enzymes are released into milk after the lysis of SCC (e.g., lipoprotein lipase; Li et al., 2014). Lipoprotein lipase activities were detected in high SCC milk (Azzara and Dimick, 1985);

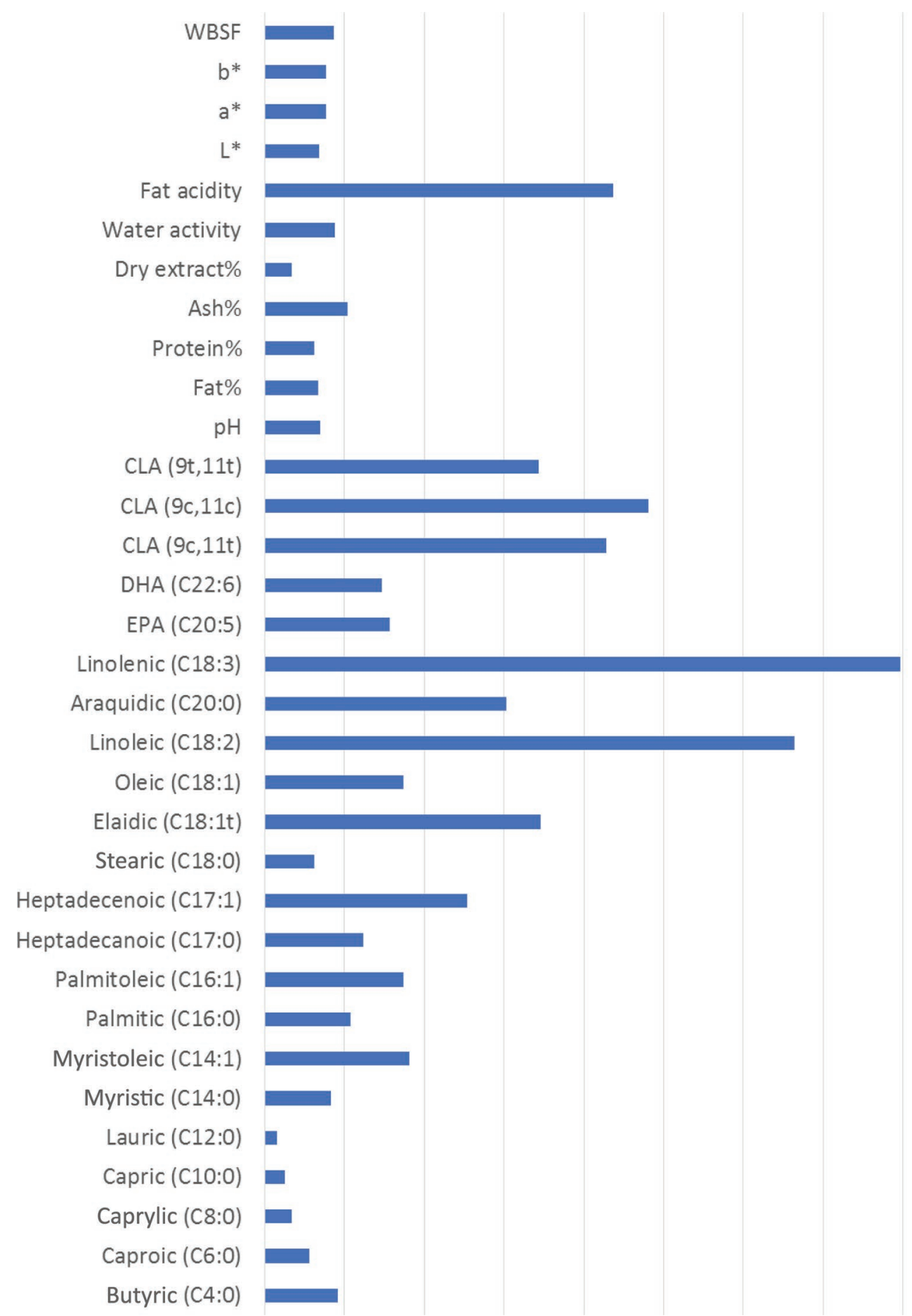

Figure 2. Quadratic weight of each of the inputs. $\mathrm{t}=$ trans; $\mathrm{c}=$ cis; $\mathrm{EPA}=$ eicosapentaenoic acid; DHA $=$ docosahexaenoic acid; $\mathrm{L}^{*}=$ lightness; $\mathrm{a}^{*}=$ redness; $\mathrm{b}^{*}=$ yellowness; WBSF $=$ Warner-Bratzler shear force. 
this enzyme participates in the production of free fatty acid in milk during storage ( $\mathrm{Li}$ et al., 2014) as milk with a high SCC is more susceptible to lipolysis (Santos et al., 2003). Lipoprotein lipases are generally considered to be causative of flavor defaults such as rancidness in some dairy products (Li et al., 2014).

\section{CONCLUSIONS}

The results of this study showed that ANN constitute a reliable tool for predicting the somatic cell level in milk used to produce cheeses from the physicochemical data measured in them. The application of ANN has shown that linoleic acid, linolenic acid, and CLA isomers are the compounds that seem to be strongly related to the changes caused by the SCC in the composition of sheep milk. Furthermore, fat acidity is the parameter that makes the greatest contribution to the possible prediction of the SCC of the milk used in the production of sheep cheese. Application of ANN with a high number of inputs could be the key to establishing the effects of SCC on cheese quality together with the correlation that exists between enzyme activity and SCC levels.

\section{ACKNOWLEDGMENTS}

The authors are grateful to the Regional Government of the Spanish region of Castilla y León (SA066/04) for its financial support.

\section{REFERENCES}

Albenzio, M., M. Caroprese, A. Santillo, R. Marino, L. Taibi, and A. Sevi. 2004. Effects of somatic cell count and stage of lactation on the plasmin activity and cheese-making properties of ewe milk. J. Dairy Sci. 87:533-542.

Albenzio, M., A. Santillo, M. Caroprese, L. Schena, D. E. Russo, and A. Sevi. 2011. Composition, indigenous proteolytic enzymes and coagulating behavior of ewe milk as affected by somatic cell count. J. Dairy Res. 78:442-447.

AOAC International. 1995. Official Methods of Analysis, vol. 4, 16th ed. AOAC International, Arlington, VA.

AOAC International. 2000. Official Methods of Analysis of AOAC International. 17th ed. AOAC International Gaithersburg, MD.

Azzara, C. D., and P. S. Dimick. 1985. Lipoprotein lipase activity of milk from cows with prolonged subclinical mastitis. J. Dairy Sci. 68:3171-3175.

Barile, D., J. D. Coisson, M. Arlorio, and M. Rinaldi. 2006. Identification of production area of Ossolano Italian cheese with chemometric complex approach. Food Control 17:197-206.

Basheer, I. A., and M. Hajmeer. 2000. Artificial Neural Networks: Fundamentals, computing and design and application. J. Microbiol. Methods 43:3-31

Berry, M. J. A., and G. Linoff. 1997. Data Mining Techniques: For Marketing, Sales and Customer Support. John Wiley \& Sons, New York, NY.

Borguer, Z., and H. Guterman. 1997. Knowledge extraction from artificial neural network models. Pages 3030-3035 in IEEE International Conference on Systems, Man and Cybernetics, Orlando, FL.
Boyazoglu, J., and P. Morand-Fehr. 2001. Mediterranean dairy sheep and goat products and their quality. A critical review. Small Rumin. Res. 40:1-11.

Carboni, P., C. Manis, I. Ibba, M. Contu, V. Coroneo, and P. Scano. 2017. Compositional profile of ovine milk a high somatic cell count: A metabolomics approach. Int. Dairy J. 69:33-39.

Cevoli, C., L. Cerretani, A. Gori, M. F. Caboni, T. Gallina Toschi, and A. Fabbri. 2011. Classification of Pecorino cheeses using electronic nose combined with artificial neural network and comparison with GC-MS analysis of volatile compounds. Food Chem. 129:13151319 .

Cevoli, C., A. Gori, M. Nocetti, L. Cuibus, M. F. Caboni, and A. Fabbri. 2013. FT-NIR and FT-MIR spectroscopy to discriminate competitors, non-compliance and compliance grated Parmigiano Reggiano cheese. Food Res. Int. 52:214-220.

CIE. 1975. Commission Internationale de L'Eclariage, 18th session, Publication 23. London, UK.

Coelho, V. R. P., C. E. C. Rodrigues, C. H. Corassin, C. F. Balthazar, L. P. Cappato, M. V. S. Ferreira, A. G. Bruzz, and C. A. F. Oliveira. 2017. Milk with different somatic cells counts and the physicochemical, microbiological characteristics and fatty acid profile of pasteurized milk cream: Is there an association? Int. J. Food Sci. Technol. 52:2631-2636.

Concha, C., O. Holmberg, and G. Astrom. 1986. Cells found in no infected and Staphylococcus-infected bovine mammary quarter and their ability to phagocytose fluorescent microspheres. Zentralbl. Veterinarmed. B 33:371-378.

Cruz, A. G., R. S. Cadena, M. B. V. B. Alvaro, A. S. Sant'Ana, C. A F. Oliveira, J. A. F. Faria, H. M. A. Bolini, and M. M. C. Ferreira. 2013. Assessing the use of different chemometric techniques to discriminate low-fat and full-fat yogurts. Lebensm. Wiss. Technol. $50: 210-214$

Cruz, A. G., R. S. Cadena, J. A. F. Faria, C. A. F. Oliveira, R. N. Cavalcanti, E. Bona, H. M. A. Bolini, and M. A. A. P. da Silva. 2011. Consumer acceptability and purchase intent of probiotic yoghurt with added glucose oxidase using sensometrics, artificial neural networks and logistic regression. Int. J. Dairy Technol. 64:549-556.

Druz, A. G., E. H. M. Walter, R. S. Cadena, J. A. F. Faria, H. M. A Bolini, and A. M. Frattini Fileti. 2009. Monitoring the authenticity of low-fat yogurts by an artificial neural network. J. Dairy Sci. 92:4797-4804

Demuth, H., and M. Beale. 1994. Neuronal Network Toolbox User's Guide. The Mathworks Inc., Natick, MA

Dulin, A. M., M. J. Paape, W. D. Schultze, and B. T. Weinland. 1983 Effect of parity, stage of lactation and intramammary infection on concentration of somatic cells and cytoplasmic particles in goat milk. J. Dairy Sci. 66:2426-2433.

EC. 2004. EC 853/2004 Regulation of the European Parliament and of the Council of 29 April 2004 laying down specific hygiene rules for on the hygiene of foodstuffs.

Etzion, Y., R. Linker, U. Cogan, and I. Shmulevich. 2004. Determination of protein concentration in raw milk my mid-infrared Fourier transform infrared/attenuated total reflectance spectroscopy. J. Dairy Sci. 87:2779-2788.

Fox, P. F., T. P. Guinee, T. M. Cogan, and P. L. H. McSweeney. 2000. Fundamentals of Cheese Science. Aspen Publishers Inc., Gaithersburg, MD.

Funahashi, H., and J. Horiuchi. 2008. Characteristics of the churning process in continuous butter manufacture and modelling an artificial neural network. Int. Dairy J. 18:323-328.

Gargouri, H., H. Hamed, and A. Elfeki. 2008. Total and differential bulk cow milk somatic cell counts and their relation with lipolysis. Livest. Sci. 113:274-279.

Gonzalo, C., A. Tardáguila, A. Ariznabarreta, M. Romeo, V. Monitoro, M. D. Pérez-Guzmán, and Y. J. C. Marco. 2000. Recuentos de células somáticas en el ganado ovino lechero y estrategias de control. Situacion en España. (Somatic cell counts in ovine dairy herd and control strategies. Spanish situation). Ovis 66:21-27.

Gori, A., R. M. Maggio, L. Cerretani, M. Nocetti, and M. F. Caboni. 2012. Discrimination of grated cheeses by Fourier transform infra- 
red spectroscopy coupled with chemometric techniques. Int. Dairy J. $23: 115-120$

Goyal, S., and G. K. Goyal. 2012. Artificial neural networks for dairy industry: A review. J. Advanced Computer Sci. Technol. 1:101105

He, Y., S. Feng, X. Deng, and X. Li. 2005. Study on lossless discrimination of varieties of yogurt using the Visible/NIR-spectroscopy. Food Res. Int. 39:645-650.

Hettinga, K. A., H. J. F. van Valenberg, and A. C. M. van Hooijdonk. 2008. Quality control or raw cow's milk by headspace analysis. Int. Dairy J. 18:506-513.

Horiuchi, J., T. Shimada, H. Funahashi, K. Tada, M. Kobayashi, and T. Kanno. 2004. Artificial neural network model with a culture database for prediction of acidification step in cheese production. J. Food Eng. 63:459-465.

IDF. 1969. International Standard. FIL-IDF 1A:1969 (International Dairy Federation, Brussels, Belgium.).

IDF. 1982. Cheese and processed cheese. Determination of the total solid content. Standard 4A. International Dairy Federation, Brussels, Belgium.

Irigoyen, A., J. M. Izco, F. C. Ibañez, and P. Torre. 2000. Evaluation of the effect of rennet type on casein proteolysis in an ovine milk cheese by means of capillary electrophoresis. J. Chromatogr. A 881:59-67.

ISO. (International Organization for Standardization). 1975. Cheese. Determination of fat content. Van Gulik method (ISO 3433). ISO, Geneva, Switzerland.

ISO. 2001. ISO 14156:2001. Milk and milk products. Extraction methods for lipids and liposoluble compounds. ISO, Geneva, Switzerland.

Jaeggi, J. J., S. Govindasamy-Lucey, Y. M. Berger, M. E. Johnson, B. C. McKusick, D. L. Thomas, and W. L. Wendorff. 2003. Hard ewe's milk cheese manufactured from milk of three different groups of somatic cell counts. J. Dairy Sci. 86:3082-3089.

Jimenez-Marquez, S. A., C. Lacroix, and J. Thibault. 2003. Impact of modeling parameters on the prediction of cheese moisture using neural networks. Comput. Chem. Eng. 27:631-646.

Jimenez-Marquez, S. A., J. Thibault, and C. Lacroix. 2005. Prediction of moisture in cheese of commercial production using neural networks. Int. Dairy J. 15:1156-1174.

Kalantzopoulos, G., J. P. Dubeuf, F. Vallerand, A. Pirisi, E. Casalta, A. Laurte, and T. Trujillo. 2004. Characteristics of sheep and goat milks: Quality and hygienic factors for the sheep and goat dairy sectors. Bulletin of IDF 390:17-28.

Karoui, R., and J. De Baerdemaeker. 2007. A review of the analytical methods coupled with chemometric tools for the determination of the quality and identity of dairy products. Food Chem. 102:621-640.

Khanmohammadi, M., A. B. Gramarudi, K. Ghasemi, S. Garrigues, and M. de la Guardia. 2009. Artificial neural network for quantitative determination of total protein in yogurt by infrared spectrometry. Microchem. J. 91:47-52.

Laurinaviciute, V., J. Siugzdaite, and D. Urbsienne. 2004. Quality and composition of milk with different somatic cell count of two breeds of dairy goats. Med. Weter. 60:1168-1170.

Le Roux, Y., F. Laurent, and F. Moussaoui. 2003. Polymorphonuclear proteolytic activity and milk composition change. Vet. Res. 34:629-645.

Leitner, G., M. Chaffer, Y. Caraso, E. Ezra, D. Kababea, M. Winkler, M. Winkler, A. Glickman, and A. Saran. 2003. Udder infection and milk somatic cell count, NAGase activiy and milk composition-fat, protein and lactose in Israeli-Assaf and Awassi sheep. Small Rumin. Res. 49:157-164.

Leitner, G., E. Shoshani, O. Krifucks, M. Chaffer, and A. Saran. 2000. Milk leucocyte population patterns in bovine udder infection of different etiology. J. Vet. Med. B 47:581-589.

Li, N., R. Richoux, M. Boutinaud, P. Martín, and V. Gagnaire. 2014. Role of somatic cells on dairy processes and products: A review. Dairy Sci. Technol. 94:517-538.

Lurueña-Martínez, M. A., C. Palacios, A. M. Vivar-Quintana, and I. Revilla. 2010a. Effect of the addition of calcium soap to ewes' diet on fatty acid composition of ewe milk and subcutaneous fat of suckling lambs reared on ewe milk. Meat Sci. 84:677-683.

Lurueña-Martínez, M. A., I. Revilla, P. Severiano-Pérez, and A. M. Vivar-Quintana. 2010b. The influence of breed on the organoleptic characteristics of Zamorano sheep's raw milk cheese and its assessment by instrumental analysis. Int. J. Dairy Technol. 63:216-223.

Marino, R., T. Considine, A. Sevi, P. L. H. McSweeney, and A. L. Kelly. 2005. Contribution of proteolytic activity associated with somatic cells in milk to cheese ripening. Int. Dairy J. 15:1026-1033.

Menzies, P. I., and Z. S. Ramanoon. 2001. Mastitis of sheep and goats. Vet. Clin. North Am. Food Anim. Pract. 17:333-358.

Munro, G. L., P. A. Grieve, and B. J. Kitchen. 1984. Effects of mastitis on milk yield, milk composition, processing properties and yield and quality of milk products. Aust. J. Dairy Technol. 39:7-16.

Nudda, A., M. Feligini, G. Battacone, N. P. P. Macciotta, and G. Pulina. 2003. Effects of lactation stage, parity, $\beta$-lactoglobulin genotype and milk SCC on whey protein composition in Darda dairy ewes. Ital. J. Anim. Sci. 2:29-39.

O'Farrell, I. P., J. J. Sheehan, M. G. Wilkinson, D. Harrington, and A. L. Kelly. 2002. Influence of addition of plasmin or mastitis milk to cheese milk on quality of smear-ripened cheese. Lait 82:305-316.

Paquet, J., C. Lacroix, and J. Thibault. 2000. Modeling of $\mathrm{pH}$ and acidity for industrial cheese production. J. Dairy Sci. 83:23932409.

Pavia, M., A. J. Trujillo, E. Sendra, B. Guamis, and V. Ferregut. 2000. Free fatty acid content of Manchego-type cheese salted by brine vacuum impregnation. Int. Dairy J. 10:563-568.

Pillonel, L., U. Bütikofer, H. Schlichtherle-Cerny, R. Tabacchi, and J. O. Bosset. 2005. Geographic origin of European Emmental. Use of discriminant analysis and artificial neural network for classification purposes. Int. Dairy J. 15:557-562.

Pinto, G., S. Caira, M. A. Nicolai, R. Mauriello, M. Cuollo, A. Pirisi, G. Piredda, L. Chianese, and F. Addeo. 2013. Proteolysis and partial dephosphorylation of casein are affected by high somatic cell counts in sheep milk. Food Res. Int. 53:510-521.

Pirisi, A., G. Piredda, M. Corona, M. Pes, S. Pintus, and A. Ledda. 2000. Influence of somatic cell count on ewe's milk composition, cheese yield and cheese quality. Pages 47-59 in Proc. 6th Great Lakes Dairy Sheep Symposium, Ontario, Canada.

Pirisi, A., G. Piredda, F. Podda, and S. Pintus. 1996. Effect of somatic cell count on sheep milk composition and cheese making properties. Pages 241-251 in Somatic Cells and Milk of Small Ruminants. EAAP Publ. no. 77. R. Rubino, ed. Wageningen Press, Wageningen, the Netherlands.

Poutrel, B. 1981. Les mammites de la chèvre et de la brebis. Pages 214-233 in Proc. 6ème Journées de la Recherche Ovine et Caprine, Paris, France.

Revilla, I., M. A. Lurueña-Martínez, and A. M. Vivar-Quintana. 2009a. Influence of somatic cell counts and breed on physico-chemical and sensory characteristics of hard ewes'-milk cheeses. J. Dairy Res. $76: 283-289$.

Revilla, I., J. M. Rodríguez-Nogales, and A. M. Vivar-Quintana. 2007. Proteolysis and texture of hard ewes' milk cheese during ripening as affected by somatic cell counts. J. Dairy Res. 74:127-136.

Revilla, I., J. M. Rodríguez-Nogales, and A. M. Vivar-Quintana. 2009b. Effect of somatic cell counts on ewes' milk protein profile and cheese-making properties in different sheep breeds reared in Spain. J. Dairy Res. 76:210-215.

Revilla, I., J. M. Rodríguez-Nogales, and A. M. Vivar-Quintana. 2011. Effects of somatic cells on the protein profile of hard ovine cheese produced from different breeds. J. Dairy Res. 78:279-286.

Rodríguez-Nogales, J. M., A. M. Vivar-Quintana, and I. Revilla. 2007. Influence of somatic cell count and breed on capillary electrophoretic protein profiles of ewes' milk: A chemometric study. J. Dairy Sci. 90:3187-3196.

Rohm, H., and D. Jaros. 1997. Color of hard cheese. Factors of influence and relation to compositional parameters. Zeitschrift für Lebensmitteluntersuchung und -Forschung A 204:259-264.

Sánchez-Macías, D., M. Fresno, I. Moreno-Indias, N. Castro, A. Morales-delaNuez, S. Álvarez, and A. Argüello. 2010. Physicochemi- 
cal analysis of full-fat, reduced-fat, and low-fat artisan-style goat cheese. J. Dairy Sci. 93:3950-3956.

Santos, M. V., Y. Ma, Z. Caplan, and D. M. Barbano. 2003. Sensory threshold of off-flavors caused by proteolysis and lipolysis in milk. J. Dairy Sci. 86:1601-1607.

Sepúlveda-Varas, P., K. L. Proudfoot, D. M. Weary, and M. A. von Keyserlingk. 2014. Changes in behavior of dairy cows with clinical mastitis. Appl. Anim. Behav. Sci. 175:8-13.

Singh, R. R. B., A. P. Ruhil, D. K. Jain, S. S. Patel, and G. R. Patil. 2009. Prediction of sensory quality of UHT milk-A comparison of kinetic and neural network approaches. J. Food Eng. 92:146-151.

Soto-Barajas, M. C., M. I. González-Martín, J. Salvador-Esteban, J. M. Hernández-Hierro, V. Moreno-Rodilla, A. M. Vivar-Quintana, I. Revilla, I. Lobos Ortega, R. Morón-Sancho, and B. Curto-Diego. 2013. Prediction of the type of milk and degree of ripening in cheese by means of artificial neural networks with data concerning fatty acids and near infrared spectroscopy. Talanta 116:50-55.

Sousa, M. J., Y. Ardö, and P. L. H. McSweeney. 2001. Advances in the study of proteolysis during cheese ripening. Int. Dairy J. 11:327345
Souza, S. S., A. G. Cruz, E. H. M. Walter, J. A. F. Faria, R. M. S. Celeghini, M. M. C. Ferreira, D. Grantao, and A. S. Sant'Ana., 2011. Monitoring the authenticity of Brazilian UHT milk: A chemometric approach. Food Chem. 124:692-695.

Verdini, R. A., S. E. Zorrilla, A. C. Rubiolo, and S. Nakai. 2007. Multivariate statistical methods for Port Salut Argentino cheese analysis based on ripening time, storage conditions, and sampling sites. Chemom. Intell. Lab. Syst. 86:60-67.

Vlaeminck, B., V. Fievez, S. Tamminga, R. J. Dewhurst, A. van Vuuren, D. De Brabander, and D. Demeyer. 2006. Milk odd- and branched-chain fatty acids in relation to the rumen fermentation pattern. J. Dairy Sci. 89:3954-3964.

Zeppa, G., M. Giordano, M. Bertolino, and V. Gerbi. 2005. Application of artificial neural network on mono- and sesquiterpenes compounds determined by headspace solid-phase microextraction-gas chromatography-mass spectrometry for Piedmont ricotta cheese traceability. J. Chromatogr. A 1071:247-253.

Zeppa, G., M. Giordano, V. Gerbi, and M. Arlorio. 2003. Fatty acid composition of Piedmont "Ossolano" cheese. Lait 83:167-173. 